\title{
Loss of $\mathrm{Nrf2}$ accelerates ionizing radiation-induced bone loss by upregulating RANKL
}

\author{
Tapasi Rana ${ }^{a}$, Michelle A. Schultz ${ }^{a}$, Michael L. Freeman ${ }^{a, b}$, and Swati Biswas ${ }^{a, b,{ }^{*}}$ \\ aDepartment of Radiation Oncology 1161 21st Avenue S MCN DD1218 Nashville, TN 37232 \\ United States

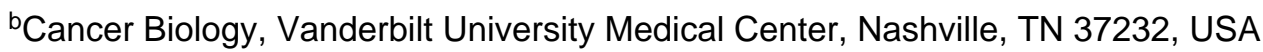

\section{Abstract}

Radiation therapy is an integral part of treatment for cancer patients; however, major side effects of this modality include aberrant bone remodeling and bone loss. Ionizing radiation (IR) is a major external factor that contributes to a significant increase in oxidative stress such as reactive oxygen species (ROS), has been implicated in osteoporotic phenotypes, and has been implicated in osteoporotic phenotypes, bone loss, and fracture risk. One of the major cellular defenses against heightened oxidative stress is mediated by nuclear factor (erythroid-derived 2)-like 2 (Nrf2), a master transcription factor that regulates induction of antioxidant gene expression and phase II antioxidant enzymes. Our objective was to test the hypothesis that loss of functional Nrf2 increases radiation-induced bone loss. We irradiated (single dose, $20 \mathrm{~Gy}$ ) the hindlegs of age- and sex-matched $\mathrm{Nrf}^{+/+}$and $\mathrm{Nrf}^{-/-}$mice. After 1 month, microCT analysis and histology revealed a drastic overall decrease in the bone volume after irradiation of mice lacking Nrf2. Although radiation exposure led to bone loss in mice with intact Nrf2, it was dramatically enhanced by loss of Nrf2. Furthermore, in the absence of Nrf2, a decrease in osteoblast mineralization was noted in calvarial osteoblasts compared with wild-type controls, and treatment with a common antioxidant, $\mathrm{N}$-acetyl-L-cysteine (NAC), was able to rescue the mineralization. As expected, we observed a higher number of osteoclasts in $\mathrm{Nrf}^{-/-}$mice compared to $\mathrm{Nrf}^{+/+}$mice, and after irradiation, the trend remained the same. RT-PCR analysis of calvarial osteoblasts revealed that in the absence of Nrf2, the expression of RANKL was increased after irradiation. Interestingly, RANKL expression was suppressed when the calvarial osteoblasts were treated with NAC before IR exposure. Taken together, our data suggest that loss of Nrf2 leads to heightened oxidative stress and increased susceptibility to radiation-induced bone loss.

\section{Keywords}

Ionizing radiation; Bone loss; Oxidative stress; $N$-acetylcysteine; Osteoblast differentiation; RANKL; Nrf2; Reactive oxygen species; Free radicals

Radiation therapy is one of the most effective and indispensable treatment modalities for cancer patients and is used both for effective control of local disease and for palliative care. However, the use of radiotherapy is often associated with normal tissue injury, which

\footnotetext{
(C) 2012 Elsevier Inc. All rights reserved.

*Corresponding author at: Department of Radiation Oncology 1161 21st Avenue S MCN DD1218 Nashville, TN 37232 United States. Fax: +(6 15$) 343$ 3061. swati.biswas@ vanderbilt.edu (S. Biswas).

Appendix A. Supporting information

Supplementary data associated with this article can be found in the online version at http://dx.doi.org/10.1016/j.freeradbiomed. 2012.10.536.
} 
includes both immediate and long-term damage to the soft tissues and bone. Radiation therapy has been implicated in increased osteoporosis and fracture risk among cancer survivors [1-3]. Therapeutic doses of ionizing radiation (IR) have been observed to have deleterious consequences for bone health in patients of all ages, occasionally causing back pain and spontaneous injury [4]. In preclinical models it has been shown that even low-dose whole-body irradiation of mice resulted in marked trabecular bone loss [5]. In addition, decreases in serum bone formation markers, bone mineral density (BMD), and ex vivo osteoblast differentiation were also noted in adult male C57BL/6 mice after irradiation [6]. Data from clinical and preclinical studies have reported that exposure to IR leads to bone damage by affecting the survival of bone marrow stromal cells [7], often reflected by low $\mathrm{BMD}$, increased fragility, and fracture risk $[8,9]$.

It is generally accepted that exposure to IR increases oxidative stress, which contributes to both short-term and long-term radiation-induced tissue injury. In vitro irradiation of osteogenic cells from the bone marrow leads to increased generation of reactive oxygen species (ROS) [10], one of the major factors implicated in increased oxidative stress and bone damage. Several in vitro and in vivo studies have reported that increased oxidative stress has a negative impact on bone formation by modulating the differentiation and survival of osteoblasts $[11,12]$. In addition, increased ROS also activate osteoclasts, thereby contributing to increased bone resorption $[13,14]$. Recent clinical studies have also shown that ROS accumulation and dysregulation of the antioxidant system are important mediators of bone loss [15-20].

Nuclear factor (erythroid-derived 2)-like 2 (Nrf2) is a ubiquitously expressed transcription factor that plays a protective role against xenotoxic stress. Nrf2 has a highly conserved leucine zipper structure and belongs to the cap-n-collar family and has been implicated in regulating both chondrogenesis and osteo-blastogenesis [21]. By forming heterodimers with the small musculoaponeurotic fibrosarcoma oncogene family proteins, Nrf2 mediates the selective recognition of antioxidant-response elements or electrophile-response elements on target genes and regulates the expression of phase II detoxifying enzymes [22,23] such as heme oxygenase-1, catalase, glutamate-cysteine ligase, and superoxide dismutase. It has been previously reported that Nrf2 controls the susceptibility of bone marrow stromal cells to oxidative stress [24] and that in the absence of Nrf2, cells become more susceptible to toxic xenobiotic stress [25-27]. In vivo imaging studies using murine models have demonstrated that one way Nrf2 offers this cellular protection is by reducing ROS [28], suggesting that in the absence of Nrf2, cells may not be able to suppress induction of ROS resulting from IR exposure. In agreement with that, $\mathrm{Nrf} 2$ has been implicated in protecting against acute pulmonary injury and hyperoxia [29-31]. In addition, loss of Nrf2 function has been implicated in inflammatory and autoimmune diseases as well as fibrosis [32,33], which are often mediated by imbalances in the redox system. Moreover, the plasma level of activity of superoxide dismutase, an enzyme regulated by Nrf2, has been negatively associated with lower BMD in patients [34,17]. Using an experimental arthritis model, it was recently reported that Nrf2 plays a critical role in oxidative stress-induced cartilage degradation. Interestingly, activation of osteoclasts by ROS has been noted during enhanced bone resorption [14] and it was demonstrated by Lee et al. [35] that receptor activator of nuclear factor $\mathrm{kB}$ ligand (RANKL) mediates ROS production in osteoclast precursor cells. Given the role of oxidative stress in bone loss and the central role of Nrf2 in maintaining redox balance, we hypothesized that Nrf2 plays a crucial role in bone remodeling and overall bone homeostasis by maintaining normal levels of ROS. We further anticipate that, in the absence of $\mathrm{Nrf} 2$, exposure to IR may lead to increased bone loss.

To investigate whether Nrf2 plays a protective role against IR-mediated bone loss, we have used a Nrf2 knockout mouse model and have demonstrated that, in the absence of functional 
Nrf2, bone marrow stromal cells show an increase in oxidative stress accompanied by suppression of osteoblast differentiation. In addition, after IR exposure, an increase in the RANKL/osteo-protegerin (OPG) ratio was observed in the conditioned medium obtained from $\mathrm{Nrf}^{-/-}$calvarial osteoblasts, suggesting a possible mechanistic link between $\mathrm{Nrf} 2$ expression and extent of IR-mediated bone loss. Finally, prior treatment with $N$ acetylcysteine (NAC) was able to suppress RANKL expression after IR exposure, suggesting that IR-induced bone loss in $\mathrm{Nr}_{\mathrm{f}} \mathrm{2}^{-/}$mice is, at least partially, mediated via increased oxidative stress. To our knowledge, this is the first report of Nrf2 playing a central role in oxidative stress-mediated bone damage.

\section{Materials and methods}

\section{Study design}

Age- and sex-matched $\mathrm{Nrf}^{+/+}$and $\mathrm{Nrf}^{-/-}$mice were used for all the experiments. Mice were irradiated ( $20 \mathrm{~Gy}$, single dose) on both hindlegs, when applicable, at the age specified for each experiment. Several in vivo and ex vivo experiments were performed to assess overall bone volume and cellular and molecular changes associated with radiation exposure in the absence or presence of functional Nrf2.

\section{Animals and genotyping}

All procedures were performed with the approval of the Vanderbilt University Institutional Animal Care and Use Committee and in accordance with federal guidelines. All experiments were performed using a well-characterized colony of C57BL/6J mice that originated from crossing a $129 / \mathrm{Sv}-\mathrm{Nfe} 212^{\mathrm{tm}}$ mouse into a C57BL background as described previously [36].

\section{Radiation exposure}

Mice were anesthetized using ketamine $(100 \mathrm{mg} / \mathrm{ml})$ and xylazine $(100 \mathrm{mg} / \mathrm{ml})$ and secured on a platform for radiation exposure. When applicable, both hindlegs of each mouse were irradiated (20 Gy, single dose, anterior) with $300 \mathrm{kVp} \mathrm{X-rays} \mathrm{at} \mathrm{a} \mathrm{rate} \mathrm{of} 2.4 \mathrm{~Gy} / \mathrm{min}$. Morbidity was assessed daily throughout the duration of the experiment. Any mouse exhibiting signs of distress, including lethargy, hunched back, ruffled fur, or increased breathing frequency, was sacrificed and excluded from the study. Compared to the radiation therapy in clinical practice a single dose of $20 \mathrm{~Gy}$ in a single fraction might be above the commonly used dose per fraction. However, patients often receive a total dose in excess of $20 \mathrm{~Gy}$, such as in stereotactic body radiosurgery (SBRT), which is a radiotherapy technique that refers to the delivery of a high-dose, tissue-ablative fraction of radiotherapy. The typical dose for SBRT is 50 Gy delivered in five fractions (10 Gy per fraction). However, some institutions administer single fractions of up to $26 \mathrm{~Gy}$ [37]. Radiation therapy is one of the common treatment modalities in pediatric oncology, and bone deformities and shortening is a dose-limiting factor for young patients. It has been reported in the literature that a dose of 15 Gy or above may cause growth arrest [38]. In addition other studies using rodent models have also used 10-35 Gy single doses to assess the effect of radiation on the biomechanical properties of [39]. Jia et al. have reported that an abdominal dose up to $20 \mathrm{~Gy}$ in mice may cause rapid bone loss [6]. Therefore, we chose to use a 20-Gy dose in our studies to mimic the effect of ionizing radiation on bone remodeling.

\section{Quantitative micro-computed X-ray tomography (microCT)}

MicroCT was used to measure trabecular bone volume within the metaphysis of the tibia as described earlier [40]. In brief, the long axis of each specimen was aligned with the scanning axis. Approximately 150 slices from the proximal tibia were scanned at a $12-\mu \mathrm{m}$ resolution ( $\mu$ CT40; Scanco Medical, Brüttisellen, Switzerland). Images were acquired using $55 \mathrm{kV}$, 
$114 \mu \mathrm{A}, 300-\mathrm{ms}$ integration, and 500 projections per $180^{\circ}$ rotation. Contiguous crosssectional images of the entire metaphyseal region were acquired. After reconstruction, the bone tissue was segmented from air or soft tissue using a threshold of 270 per thousand (or $438.7 \mathrm{mg} \mathrm{HA} / \mathrm{cm}^{3}$ ), a Gaussian noise filter of 0.8 , and support of 2 . Trabecular bone volume and connectivity density were calculated using the Scanco evaluation software.

\section{Bone histomorphometry}

After sacrifice, hindlimbs (tibiae and femora) from each mouse were harvested, fixed in $10 \%$ neutral-buffered formalin (Fisher Scientific) for 3-4 days, and stored in 70\% ethanol for further processing. The tibiae and femora were decalcified in $10 \%$ EDTA-NaOH solution ( $\mathrm{pH} 7$ ) for 21 days and embedded in paraffin for histological analysis. Sections (5-7 $\mu \mathrm{m}$ ) for histomorphometry were stained with hematoxylin, orange $\mathrm{G}$, and phloxine B. TRAP staining was done using a leukocyte acid phosphatase kit (Sigma). Histomorphometric analyses of bone volume, osteoclast numbers, and osteoblast numbers were performed on digital micrographs using Metamorph software [40].

\section{Cell cycle analysis}

After irradiation at $20 \mathrm{~Gy}$, both bone marrow stromal cells and bone marrow mononuclear cells from $\mathrm{Nrf}^{+/+}$and $\mathrm{Nrf}^{-/-}$mice were incubated for $24 \mathrm{~h}$. After incubation, cells were collected and washed with phosphate-buffered saline (PBS) and fixed with ice-cold 70\% ethanol at $4{ }^{\circ} \mathrm{C}$ for $30 \mathrm{~min}$. Cells were further washed in PBS after incubation with $250 \mu \mathrm{g} /$ $\mathrm{ml}$ RNase A (BD Biosciences) at $37^{\circ} \mathrm{C}$ for $10-15 \mathrm{~min}$ and stained using $10 \mu \mathrm{g} / \mathrm{ml}$ propidium iodide (Sigma) for $15 \mathrm{~min}$ on ice. A set of nonirradiated control cells from both genotypes was also fixed and stained similarly. DNA content of the samples was analyzed using flow cytometry. Approximately $10^{4}$ cells per sample were analyzed and the data presented here are representative of at least two experiments using triplicate samples. Fluorescence data are presented as percentages of the total population.

\section{Measurement of cellular ROS by flow cytometry}

Femora and tibiae were collected from 2-month-old sex-matched $\mathrm{Nrf}^{+/+}$and $\mathrm{Nrf}^{-/-}$mice. Using a mixture of PBS and antibiotics (2000 U/ml penicillin and $2000 \mathrm{U} / \mathrm{ml}$ streptomycin), bone marrow cells were collected from the femurs and were resuspended (a-MEM, 10\% fetal bovine serum (FBS), $2000 \mathrm{U} / \mathrm{ml}$ penicillin, $2000 \mathrm{U} / \mathrm{ml}$ streptomycin, and $250 \mu \mathrm{g} / \mathrm{ml}$ Fungizone) and plated in tissue culture flasks and returned to a cell culture incubator $\left(37{ }^{\circ} \mathrm{C}\right.$, $5 \% \mathrm{CO}_{2}$ ). After $2-3$ days, adherent and non-adherent cells were collected separately and used for ROS assays using 2,7-dicholorofluorescein diacetate (Molecular Probes) according to the manufacturer's instructions. In brief, cells were trypsinized, washed and resuspended in PBS, irradiated at 20 Gy (radiation group only), combined with the molecular probe C400 $(10 \mathrm{mg} / \mathrm{ml})$, and incubated for $15 \mathrm{~min}$ at $37^{\circ} \mathrm{C}$. A parallel set of cells was maintained as untreated controls and included in the ROS assay. Cells were analyzed using flow cytometry for C400 oxidation [41].

\section{Western blot analysis}

Mouse calveria osteoblast lysates were used for Western blot analysis. In brief, cells were plated in T25 flasks and were allowed to attach at least overnight. Cells were treated with 20 Gy (single dose) radiation on the following day. A parallel group was kept as a nonirradiated control. After $24 \mathrm{~h}$ of radiation treatment, both nonirradiated and irradiated cells were harvested and protein lysates were prepared using a high-salt lysis buffer containing $10 \mathrm{mM}$ Hepes, $422 \mathrm{mM} \mathrm{NaCl}, 0.1 \mathrm{mM}$ EGTA, $25 \%$ glycerol, and $1.5 \mathrm{mM} \mathrm{MgCl}$. Protein estimation was done using a Bio-Rad assay (Cat. No. 500-0006). Fifty micrograms of protein from calveria osteoblast lysate was used for heme oxygenase 1 (HO1; Cat. No. 
OSA-110; Stressgene) and catalase (Cat. No. CAT-505, monoclonal; Sigma-Aldrich) expression using SDS-PAGE. Horseradish peroxide-conjugated anti-mouse (Sc-2005; Santa Cruz Biotechnology) was used for HO1 and catalase. The binding of these antibodies to the blots was detected with enhanced chemilumi-nescence (NEL104001EA; PerkinElmer) following the manufacturer's instructions. Blots were stripped and reprobed with GAPDH (Sc-32233; Santa Cruz Biotechnology) with anti-mouse secondary antibody (Sc-2005; Santa Cruz Biotechnology) to enable normalization of signals between samples. Band intensities were analyzed using ImageJ software.

\section{Determination of glutathione (GSH) level in the bone marrow stromal cells using the GSH- Glo glutathione assay}

Bone marrow stromal cells $(10,000)$ were plated using 96-well plates. After 2 days, the medium was aspirated and fresh medium added to the plates. Cells were irradiated (20 Gy) and GSH levels were measured after 1 and $19 \mathrm{~h}$ using the GSH-Glo glutathione assay kit (Promega, No. V6911) following the manufacturer's instruction.

\section{Colony forming assay}

Three-month-old sex-matched mice were irradiated in both hindlegs (20 Gy) and after 3 days bone marrow cells from tibia and femur were collected using a PBS and antibiotic mixture $(2000 \mathrm{U} / \mathrm{ml}$ penicillin and $2000 \mathrm{U} / \mathrm{ml}$ streptomycin). Cells were resuspended in medium (a-MEM, 10\% FBS, $2000 \mathrm{U} / \mathrm{ml}$ penicillin, $2000 \mathrm{U} / \mathrm{ml}$ streptomycin, $250 \mu \mathrm{g} / \mathrm{ml}$ Fungizone) and plated for colony formation assay. The CFU-F (fibroblast colony-forming unit) assay was done using $10^{5}$ cells per well and for CFU-OB (osteoblast colony forming unit) $2 \times 10^{5}$ cells per well in a six-well plate were cultured as previously described [42]. After visible colonies were noted under a microscope, the cells were fixed by $10 \%$ formalin and stained with $0.5 \%$ crystal violet for CFU-F and with VonKossa for CFU-OB. Colonies were counted under the microscope.

\section{Osteoblast mineralized matrix formation assay}

Primary cultures of calvarial osteoblasts were isolated using a modification of a sequential collagenase/trypsin digestion method [43]. In brief, calvaria were removed from 3- to 4-dayold $\mathrm{Nrf}^{2^{+/+}}$and $\mathrm{Nrf} 2^{-/-}$mice and soft tissues were cleaned, washed for 10 min with PBS containing $0.025 \%$ trypsin, digested with $10 \mathrm{mg} / \mathrm{ml}$ type IV collagenase p (Clostridium histolyticum; Roche) in a-MEM, and incubated for $30 \mathrm{~min}$ at $37^{\circ} \mathrm{C}$ with gentle shaking. The procedure was repeated twice, with a 1-h digestion followed by a 30-min digestion. The cells from the second and third digestions were collected and centrifuged at $2500 \mathrm{~g}$ for 10 $\mathrm{min}$. The medium was aspirated and discarded, and the pellet was resuspended and plated in a-MEM containing 10\% FBS. The culture was kept undisturbed for at least 2 days. At confluence, cells were trypsinized and plated in six-well plates for the osteoblast differentiation assay. Cells were cultured until confluence, at which time irradiation and/or NAC treatment was performed. For the rescue experiment, cells were treated with NAC ( 20 $\mathrm{mM}$ ) before radiation exposure. After the treatment, the cells were cultured in osteogenic medium (a-MEM containing 10\% FBS, $5 \mathrm{mM} \beta$-glycerophosphate, and $50 \mu \mathrm{g} / \mathrm{ml} \mathrm{L}$-ascorbic acid) with changes every 2 days until mineralized nodules (approx 15-21 days) formed. Mineralized matrix formation was detected by VonKossa staining, and photomicrographs were taken.

\section{Determination of RANKL by ELISA}

Mouse calveria osteoblast cells were cultured as described earlier and cultured for 3-4 days. In radiation group cells were irradiated with $20 \mathrm{~Gy}$ X-rays and after 5 days the mouse 
calverial conditional medium was collected for RANKL levels using a RANKL immune assay kit (Cat. No. MTR00; R\&D Systems) following the manufacturer's instructions.

\section{Osteoclastogenesis assays}

Osteoclast differentiation was performed as described previously [40]. Briefly, mouse long bones were flushed with PBS, resuspended by pipetting, and strained through a cell strainer (BD Biosciences; $40 \mu \mathrm{m}$ ). Mononuclear cells were isolated from resuspended bone marrow using Histopaque 1077 (Sigma) following the manufacturer's instructions. Cells were cultured for 7-10 days in a-MEM supplemented with 10\% FBS, 100ng/ml RANKL(R\&D Systems), and macrophage colony-stimulating factor (MCSF; R\&D Systems; $30 \mathrm{ng} / \mathrm{ml}$ ) to support osteoclast formation. TRAP staining was performed using a leukocyte acid phosphatase kit (Sigma) and the number of osteoclasts per field was counted under a microscope.

\section{RNA isolation, cDNA synthesis, and RT-PCR}

Mouse calvaria were collected from 3- to 4-day-old $\mathrm{Nrf2} 2^{+/+}$and $\mathrm{Nrf}^{-/-}$mice and osteoblasts were isolated and cultured as described [40]. Cells were cultured until confluence and then treated with radiation and/or NAC. Cells were harvested after $20 \mathrm{~h}$, washed with PBS, and used for RNA isolation. Total RNA was extracted using the RNeasy Mini Kit (Qiagen; Cat. No. 74104). Synthesis of cDNA from mRNA transcripts was performed using the SuperScript III first-strand synthesis kit (Invitrogen; Cat. No. 18080-051). RT-PCR was carried out according to standard procedures. Specific PCR conditions and primer design were described earlier [44]. The PCR products were electrophoresed in $2 \%$ agarose gels. Images were captured using a Bio-Rad gel documentation system and band intensities were quantified using Image-J software. The following sets of primers were used for RT-PCR: OPG, 5'GTGGTGCAAGCTGGAACCCCAG-AGGCCCTTCAAGGTGT CTTGGTC-3' (647 bp); RANKL, 5'-CGCTCTGTTCCTGTACTTTCGAGCG-CGTGCTCCCTTTCATCAGGTT-3' (587 bp); and GAPDH, 5'-CTGCAC-CACCAACTGCTTAGAGATCCACGACGGACACATT-3' (282 bp).

\section{Statistical analysis}

Student's $t$ test was used to determine the statistical significance of the results. A $P$ value of $<0.05$ was considered statistically significant. At least five or six mice per group were used for each in vivo and in vitro experiment.

\section{Results}

\section{Deletion of Nrf2 increases IR-mediated bone loss}

MicroCT analysis of the mouse tibiae revealed that upon radiation exposure, $\mathrm{Nrf} 2^{-/-}$mice showed a significant and more dramatic (2.8-fold decrease) overall bone loss (Fig. 1A) compared to wild-type mice (1.6-fold decrease). Deletion of $\mathrm{Nrf2}$ did not alter the bone volume in the absence of irradiation, at least not at 3 months of age. In mice lacking Nrf2, both trabecular bone volume $(P=0.012)$ and connectivity density $(P=0.029)$ were decreased upon radiation exposure (Fig. 1B and 1C), suggesting a possible protective role of Nrf2 against radiation-induced bone damage, especially trabecular architecture.

\section{IR exposure significantly reduces bone area in the absence of Nrf2}

A balance between osteoblastic bone formation and osteoclastic bone resorption is necessary for bone remodeling. In addition, differentiation of osteoclasts, which is a crucial event for osteoclastic bone resorption, is dependent on osteoblasts. It is well accepted in the literature 
that IR may alter bone remodeling. To assess whether loss of Nrf2 may have accelerated the process, 3-month-old $\mathrm{Nrf}^{+/+}$and $\mathrm{Nrf}^{-/-}$mice were irradiated in both hindlegs, and bone samples were collected 1 month later. Of note, previous reports have indicated that radiation exposure induced bone loss in mice 9-13 weeks of age [4,45]. Histomorphometric analysis was performed to assess the histological changes such as trabecular bone area, number of osteoblasts, and number of osteoclasts. As the data show, the average trabecular bone area (Fig. 2A) was significantly decreased in $\mathrm{Nrf}^{-/-}$mice upon radiation, whereas bone area in $\mathrm{Nrf} 2^{+/+}$mice was not $(P>0.05)$. In addition, we observed fewer osteoblasts (Fig. 2B) and more osteoclasts (Fig. 2C) in the $\mathrm{Nrf}^{-/-}$mice compared to the $\mathrm{Nrf}^{2^{+/+}}$mice, both before and after irradiation.

\section{Radiation exposure decreases survival of stromal and osteoblast populations in $\mathrm{Nrf2}^{+/+}$ and $\mathrm{Nrf2}^{-1-}$ mice}

Ex vivo culture of bone marrow stromal cells had revealed that, as such, lack of Nrf2 itself resulted in a significant decrease in the number of both stromal and osteoblast colonyforming units, suggesting that presence of functional Nrf2 is crucial for the survival of the stromal population (Fig. 3A and 3B). In addition, a decrease in CFU-OB further indicates that the stromal progenitor cell homeostasis may have been altered. Furthermore, radiation exposure negatively affected the survival of both CFU-F and CFU-OB in both $\mathrm{Nrf} 2^{+/+}$and $\mathrm{Nrf}^{-/-}$mice, suggesting that IR insult affects cell survival, regardless of the presence or absence of Nrf2. In addition, cell cycle analysis revealed that after IR exposure, bone marrow stromal cells were present in lower numbers in the G1 phase, regardless of the presence or absence of Nrf2 (Table 1).

\section{Lack of Nrf2 sensitizes calvarial osteoblasts to IR-induced decreases in osteoblast mineralization}

To investigate whether the IR-induced bone loss in the $\mathrm{Nrf}^{-/-}$mice is a reflection of decreased osteoblast differentiation, we performed an ex vivo osteoblast mineralization assay using calvarial osteoblasts from $\mathrm{Nrf}^{+/+}$and $\mathrm{Nrf}^{-/-}$mice. After $20 \mathrm{~Gy}$ irradiation, osteoblasts were cultured in the presence of osteogenic medium until mineralized nodule formation was noted (approximately 14 days). In the absence of Nrf2, osteoblasts showed a $50 \%$ decrease in matrix formation, and radiation exposure led to further decrease (Fig. 4A and 4B), suggesting that Nrf2 plays a major role in osteoblast differentiation and matrix formation, in both the presence and the absence of IR.

\section{Lack of Nrf2 increases oxidative stress in the bone marrow stromal cells}

It is well accepted that IR is a major source of oxidative stress and a number of recent studies have implicated aberrant oxida-tive stress in negatively regulated osteoblast differentiation and survival [11,12]. As Nrf2 is a major transcription factor that protects cells against oxidative stress, we hypothesized that in the absence of Nrf2, cells will become susceptible to oxidative stress and treatment with antioxidant will rescue the effect. As expected, a lack of Nrf2 resulted in a significant increase in ROS in bone marrow stromal cells compared to wild-type cells, as indicated by C400 oxidation (Fig. 5A). GSH and GSHdependent enzymes have been implicated as playing a major role in protecting cells from radiation-induced damage $[46,47]$ and Nrf2 is critical for maintaining the cellular GSH redox state and regulates many cytoprotective enzymes such as glutathione transferase and glutathione peroxidase, which are major components of GSH metabolism. To assess whether lack of Nrf2 may have any effect on the cellular glutathione levels, we measured the total GSH levels in the bone marrow stromal cells from $\mathrm{Nrf}^{+/+}$and $\mathrm{Nrf}^{-/-}$mice with or without IR exposure. A consistently lower GSH level was noted in $\mathrm{Nrf}^{-/-}$mice compared to $\mathrm{Nrf}^{+/+}$at all time points tested, and upon treatment with IR, we saw a statistically 
significant decline in GSH levels in the $\mathrm{Nrf}^{-/-}$bone marrow stroma at both time points, whereas $\mathrm{Nrf}^{+/+}$marrow showed a significant decrease in GSH levels only at $19 \mathrm{~h}$ after radiation exposure (Fig. 5B). This suggests an early induction of oxidative stress in the $\mathrm{Nrf}^{-/-}$mice compared to $\mathrm{Nrf} 2^{+/+}$. Nrf2 has been shown to play a critical role in protecting cells against oxidative stress [48] by regulating the expression of several antioxidant enzymes, such as HO1, SOD1, SOD2, GCLM, GCLC, and catalase [49-51]. Therefore we anticipated that a lack of functional Nrf2 may be associated with poor antioxidant response. We showed that at least two major antioxidant pathways, HO1 and catalase, show either no or lower induction after IR in the absence of Nrf2 (Fig. 5C and 5D), whereas $\mathrm{Nrf}^{+/+}$ osteoblasts showed induction of both proteins after IR. In addition, the level of GCLM was lower in $\mathrm{Nrf}^{-/-}$bone marrow stromal cells compared to $\mathrm{Nrf2}^{+/+}$, and no induction after radiation was noted in either genotype (Supplementary Fig. 1).

We anticipated that increased oxidative stress may have been the causal factor of lower osteoblast differentiation after IR; therefore we attempted to rescue that by pretreatment with the antioxidant NAC. We demonstrated that treatment with NAC before irradiation was able to restore osteoblast differentiation, as indicated by representative images from osteoblast cultures after VonKossa staining and quantification (Fig. 5E and 5F). These data indicate that loss of Nrf2 in mice leads to increased oxidative stress in the bone microenvironment and negatively affects osteoblast differentiation, which may be responsible, at least in part, for the IR-induced bone loss in our model.

\section{Aberrant oxidative stress is responsible for IR-mediated bone loss}

Previous reports have shown a direct effect of ROS on osteo-clastogenesis and bone formation [14]. In agreement with that, we have observed that loss of Nrf2 increases oxidative stress in bone marrow mononuclear cells (Fig. 6A) and that these cells differentiate into larger and greater numbers of osteoclasts when cultured in the presence of MCSF and RANKL (Fig. 6B). One of the major cytokines needed for osteoclast differentiation is RANKL, which is secreted by the osteoblasts. Enzyme-linked immunosorbent assays (mouse RANKL ELISA Kit; R\&D Systems) showed that the amount of RANKL increases 1.5 -fold after IR in $\mathrm{Nrf}^{-/-}$calvarial osteoblasts compared to nonirradiated controls $(P=0.02)$; however, no such increase was observed in $\mathrm{Nrf2} 2^{+/+}$ osteoblasts. In addition we measured the secreted RANKL protein levels in the conditioned medium from the calverial osteoblast culture from $\mathrm{Nrf}^{2^{+/+}}$and $\mathrm{Nrf2^{-/- }}$ mice, either in the presence or in the absence of IR Only the osteoblasts from $\mathrm{Nrf}^{-/-}$mice showed a statistically significant increase in secreted RANKL (Fig. 6C). The amount of OPG was unchanged in both genotypes after IR (data not shown). Using RT-PCR, we demonstrated that, in the absence of Nrf2, IR exposure increased RANKL expression in bone marrow stromal cells and that prior NAC treatment suppressed this induction (Fig. 6D and 6E). In $\mathrm{Nrf}^{+/+}$osteoblasts, however, the RANKL expression remained similar to that observed after irradiation.

\section{Discussion}

In this study we have investigated the protective role of Nrf2 in mediating radiation-induced bone loss, a major side effect of cancer therapy. Using a $N r f 2$ knockout mouse model we have assessed several physiological and cellular aspects of bone remodeling after IR exposure. In vivo data indicate that mice lacking Nrf2 exhibit greater bone loss after radiation exposure (Fig. 1), whereas the bone volume in the wild-type mice was unchanged. This is in agreement with the report by Cao et al. [52], in which no change in the bone volume was noted in mice after 1 or 4 weeks of X-ray radiation. Although previous reports by Hamilton et al. [4] using space radiation have shown significant bone loss in 9-week-old 
mice, space radiation is representative of long-term low-dose radiation from multiple sources, whereas X-ray exposure used here is more representative of the clinical scenario of high-dose single exposure.

Our in vivo data indicate that a lack of Nrf2 also decreased osteoblast numbers and increased osteoclast numbers, suggesting potentially aberrant bone remodeling (Fig. 2). Ex vivo culture of bone marrow precursor cells demonstrated that lack of Nrf2 negatively affects osteoblast survival, which further deteriorates upon radiation exposure (Fig. 3). However, the negative effects of radiation on the CFU-F were previously reported within 1 week of radiation [52], which supports our observation of a highly significant decrease in CFU-OB and CFU-F 3 days after radiation exposure (Fig. 3). To our knowledge, this is the first report that $\mathrm{Nrf} 2$ is a central factor, at least in part, in maintaining stromal cell homeostasis in the bone marrow. Our findings support the observation by Rasheed et al. [7] of an osteoporotic phenotype in mice lacking Atm (ataxia-telangiectasia mutated), in which failure to upregulate Nrf2 accompanies increased oxidative stress. In this report, we also demonstrate that the absence of Nrf2 from bone marrow stromal cells leads to an increase in ROS production. Our results highlight the crucial role Nrf2 plays in bone home-ostasis by protecting against xenobiotic stress [25-27].

Osteoblasts are the basic cells responsible for the synthesis of bone matrix and therefore play a vital role in bone remodeling and maintaining the structural integrity of bone [53]. In addition, upon deletion of $N r f 2$, calvarial osteoblasts showed decreased mineralization compared to wild-type controls. The mineralization was further deteriorated in both genotypes when the osteoblasts were exposed to IR, a well-known inducer of ROS. This observation validates previous reports that suggested that increased oxidative stress negatively affects bone formation by modulating the differentiation and survival of osteoblasts [11,12].

It has also been indicated that adipocytes may regulate both hematopoiesis and osteogenesis [54]. Enhanced expression of adipocyte markers in rodent stromal cells was correlated with decreased expression of an osteoblastic marker [55], and therefore, it is generally accepted that an adverse relationship exists between osteoblast differentiation and adipocyte differentiation, as factors promoting adipogenesis often inhibit osteoblastogen-esis. Of note, the differentiation of osteoblasts and adipocytes is tightly regulated and both cell types originate from a common progenitor. Using a cell culture model, Chartoumpekis et al. [56] demonstrated that during adipocyte differentiation, Nrf2 activation is decreased. This indirectly supports our finding that upon $N r f 2$ deletion, osteoblast differentiation was decreased. Increased ROS levels positively correlated with adipogenesis and are known to facilitate adipocyte differentiation [57]. Radiation exposure has also been reported to increase adipogenesis [52], most probably by increased oxidative stress. In addition, we also demonstrated a decline in GSH levels in $\mathrm{Nrf}^{-/-}$bone marrow stromal cells as early as $1 \mathrm{~h}$ after radiation exposure compared to untreated control, and the difference was maintained even after $19 \mathrm{~h}$ (Fig. 5B). This indicates a sustained oxidative stress in $\mathrm{Nrf}^{-{ }^{-1}}$ mice. In addition, we also observed that $N r f 2^{-/-}$calverial osteoblasts fail to induce the expression of two major cytoprotective enzymes, $\mathrm{HO} 1$ and catalase. Both were induced in $\mathrm{Nrf2^{+/+ }}$ cells after IR. Taken together, our data indicate that increased oxidative stress may be responsible, either partially or fully, for the decline in osteoblast differentiation. In agreement with that, our data indicate that prior treatment with NAC, a well-known antioxidant, was able to rescue osteoblast mineralization after IR in either the presence or the absence of Nrf2 (Fig. 5E and 5F), suggesting that an imbalance in the redox status may alter the osteoblastogenesis of the bone marrow precursor cells. 
Raseed et al. [7] showed in an elegant study that ATM-deficient mice also show defective osteoblast differentiation and an osteoporotic phenotype, possibly by a pathway mediated by Nrf2. However, a report by Hinoi et al. [58] showed that in osteoblastic MC3T3 cells, expression of $N r f 2$ negatively affected alkaline phosphatase activity. The authors used ovariectomized mice for an in vivo model of bone loss in which upregulation of Nrf2 was noted in the femur. We suspect their observation represents a hormone-dependent regulation of $\mathrm{Nrf} 2$, in which the bone remodeling was manipulated using ovariectomy in adult mice. This is opposite to what we have observed in our model, in which the mice were genetically lacking Nrf2 from birth. We surmise that in the ovariectomy model, Nrf2 may have a completely different role in osteoblast differentiation and bone loss, a role mediated via RUNX2. Thus, their result cannot be explained by our observations.

During normal bone remodeling, osteoblast-mediated bone formation and osteoclastmediated bone resorption occur in a tightly coupled manner. Recent reports have indicated that osteoblasts regulate the hematopoietic stem cell niche, thereby regulating osteoclast lineage in the bone [59-61]. Osteoblasts produce RANKL and MCSF, the factors essential for osteoclasto-genesis. They also produce OPG, the soluble decoy receptor for RANKL [62-65]. Therefore, osteoblasts may alter the bone micro-environment via either autocrine or paracrine mechanisms. Moreover, undifferentiated osteoblasts with high RANKL/OPG ratios can support osteoclastogenesis, but this effect diminishes in mature osteoblasts [60]. IR exposure increased RANKL expression, suggesting a causal link to increased bone loss, in the calvarial osteoblasts from $\mathrm{Nrf}^{-/-}$mice compared to $\mathrm{Nrf} 2^{+/+}$mice. In addition, treatment with NAC was able to decrease the RANKL expression after IR in the $\mathrm{Nrf}^{-/-}$ calvarial osteoblasts. These results are in agreement with the previous report in which increased oxidative stress was correlated with low bone mass and increased resorption, leading to pathological osteoporosis. In addition, treatment with $\mathrm{H}_{2} \mathrm{O}_{2}$, an inducer of oxidative stress, increased osteoclast differentiation and RANKL/OPG ratio [66].

IR exposure is known to activate the Nrf2 antioxidant response, suggesting that Nrf2 plays a crucial role in protecting cells from IR-induced damage [67]. In our murine model in which $N r f 2$ has been genetically deleted, we saw heightened oxidative stress in the bone marrow stromal cells, suggesting that a permanent deletion of this transcription factor may lead to sustained oxidative stress. Upon IR exposure, a more significant bone loss was observed in $\mathrm{Nrf} \mathrm{2}^{-/-}$mice, compared to mice with functionally intact $\mathrm{Nrf} 2$, suggesting that in the absence of Nrf2, cells were less efficient at eliminating the ROS accumulation, which may have negatively influenced bone homeostasis by disrupting crucial events necessary for bone formation. Increased ROS activate osteoclasts, which in turn increase bone resorption $[13,14]$. Similarly, we also observed that when bone marrow mononuclear cells were isolated and cultured ex vivo in the presence of RANKL and MCSF, $\mathrm{Nrf}^{-/-}$bone marrow gave rise to larger osteoclasts compared to the wild-type control cells (Fig. 6). Recent clinical studies have also shown that dysregulation of ROS and the antioxidant system is an important mediator of bone loss [15-20].

In summary, we have demonstrated a novel role for Nrf2 in osteoblast and osteoclast differentiation, which may involve a crucial role in bone remodeling. Both osteoblast differentiation and osteoclast formation were affected upon deletion of Nrf2. Although we did not observe any striking difference in overall bone volume between $\mathrm{Nrf}^{+/+}$and $\mathrm{Nrf}^{-\mathrm{I}_{-}}$ mice at 2-3 months of age, the mice lacking Nrf2 exhibited more bone loss after IR. We propose a model (Fig. 7) to explain how the IR may have contributed to the overall bone loss. In the absence of Nrf2, exposure to IR downregulates osteoblast differentiation, which in turn induces secretion of more RANKL, while OPG secretion remains the same. The overall increase in RANKL expression induces osteoclast maturation and bone resorption. This process is mediated via osteoblasts. In addition, our data indicate that IR exposure 
negatively affects osteoblast numbers, probably in a cell-autonomous manner, which negatively influences bone formation.

The majority of cancer patients receive radiation therapy either to control local or metastatic disease or as a palliative treatment to manage pain. Despite being well accepted as a therapy for cancer, radiation exposure leads to serious damage to the bone by inducing osteoporosis and fracture risk. Although radiation-induced bone loss is a major clinical problem among cancer survivors who have received radiation therapy, little is known regarding the underlying molecular mechanism of IR-induced bone loss or how the bone damage can be prevented. Cancer patients who experience bone loss often receive antire-sorptive therapies such as bisphosphonates, which are effective against bone resorption, but cannot induce new bone formation or repair the existing damage. Our data demonstrate that an antioxidant treatment may be able to rescue osteoblast differentiation, which offers an alternative approach to reducing or even reversing IR-induced bone loss in cancer patients.

\section{Supplementary Material}

Refer to Web version on PubMed Central for supplementary material.

\section{Acknowledgments}

We thank Dr. Raja Shekhar Konjeti (Department of Radiation Oncology, Vanderbilt University) for his help with the irradiator. We thank Dr. Amudhan Venkateshwaran (Department of Radiation Oncology, Vanderbilt University), Dr. Daniel Perrian (Department of Orthopaedics and Rehabilitation, Vanderbilt University Institute of Imaging Sciences, and Vanderbilt Center for Bone Biology), and Nicole Flemming (Vanderbilt University Institute of Imaging Sciences) for their technical help. We thank Ms. Ankita Joshi for her artwork in the graphical abstract and image analysis using Metamorph software. We thank Mr. Jyotishka Biswas for his help with image analysis using ImageJ and Metamorph software. The research for this study was supported by APS funding from Vanderbilt University and Vanderbilt-Ingram Cancer Center Grant P30 CA68485. Dr. Melissa Stauffer of Scientific Editing Solutions edited the manuscript.

\section{References}

1. Wall JE, Kaste SC, Greenwald CA, Jenkins JJ, Douglass EC, Pratt CB. Fractures in children treated with radiotherapy for soft tissue sarcoma. Orthopedics. 1996; 19:657-664. [PubMed: 8856775]

2. Schmeler KM, Jhingran A, Iyer RB, Sun CC, Eifel PJ, Soliman PT, Ramirez PT, Frumovitz M, Bodurka DC, Sood AK. Pelvic fractures after radiotherapy for cervical cancer: implications for survivors. Cancer. 2010; 116:625-630. [PubMed: 20052724]

3. Hopewell JW. Radiation-therapy effects on bone density. Med. Pediatr. Oncol. 2003; 41:208-211. [PubMed: 12868120]

4. Hamilton SA, Pecaut MJ, Gridley DS, Travis ND, Bandstra ER, Willey JS, Nelson GA, Bateman TA. A murine model for bone loss from therapeutic and space-relevant sources of radiation. J. Appl. Physiol. 2006; 101:789-793. [PubMed: 16741258]

5. Bandstra ER, Pecaut MJ, Anderson ER, Willey JS, De Carlo F, Stock SR, Gridley DS, Nelson GA, Levine HG, Bateman TA. Long-term dose response of trabecular bone in mice to proton radiation. Radiat. Res. 2008; 169:607-614. [PubMed: 18494551]

6. Jia D, Gaddy D, Suva LJ, Corry PM. Rapid loss of bone mass and strength in mice after abdominal irradiation. Radiat. Res. 2011; 176:624-635. [PubMed: 21859327]

7. Cao X, Wu X, Frassica D, Yu B, Pang L, Xian L, Wan M, Lei W, Armour M, Tryggestad E, Wong J, Wen CY, Lu WW, Frassica FJ. Irradiation induces bone injury by damaging bone marrow microenviron-ment for stem cells. Proc. Natl. Acad. Sci. USA. 2011; 108:1609-1614. [PubMed: 21220327]

8. Wernle JD, Damron TA, Allen MJ, Mann KA. Local irradiation alters bone morphology and increases bone fragility in a mouse model. J. Biomech. 2010; 43:2738-2746. [PubMed: 20655052] 
9. Hwang JH, Song SH, Lee JK, Lee NW, Lee KW. Bone mineral density after concurrent chemoradiation in patients with uterine cervical cancer. Menopause. 2010; 17:416-420. [PubMed: 20216278]

10. Kondo H, Yumoto K, Alwood JS, Mojarrab R, Wang A, Almeida EA, Searby ND, Limoli CL, Globus RK. Oxidative stress and gamma radiation-induced cancellous bone loss with musculoskeletal disuse. J. Appl. Physiol. 2010; 108:152-161. [PubMed: 19875718]

11. Bai XC, Lu D, Bai J, Zheng H, Ke ZY, Li XM, Luo SQ. Oxidative stress inhibits osteoblastic differentiation of bone cells by ERK and NF- $\kappa$ B. Biochem. Biophys. Res. Commun. 2004; 314:197-207. [PubMed: 14715266]

12. Mody N, Parhami F, Sarafian TA, Demer LL. Oxidative stress modulates osteoblastic differentiation of vascular and bone cells. Free Radic. Biol. Med. 2001; 31:509-519. [PubMed: 11498284]

13. Isomura H, Fujie K, Shibata K, Inoue N, Iizuka T, Takebe G, Takahashi K, Nishihira J, Izumi H, Sakamoto W. Bone metabolism and oxidative stress in postmenopausal rats with iron overload. Toxicology. 2004; 197:93-100. [PubMed: 15003320]

14. Garrett IR, Boyce BF, Oreffo RO, Bonewald L, Poser J, Mundy GR. Oxygen-derived free radicals stimulate osteoclastic bone resorption in rodent bone in vitro and in vivo. J. Clin. Invest. 1990; 85:632-639. [PubMed: 2312718]

15. Basu S, Michaelsson K, Olofsson H, Johansson S, Melhus H. Association between oxidative stress and bone mineral density. Biochem. Biophys. Res. Commun. 2001; 288:275-279. [PubMed: 11594785]

16. Maggio D, Barabani M, Pierandrei M, Polidori MC, Catani M, Mecocci P, Senin U, Pacifici R, Cherubini A. Marked decrease in plasma antioxidants in aged osteoporotic women: results of a cross-sectional study. J. Clin. Endocrinol. Metab. 2003; 88:1523-1527. [PubMed: 12679433]

17. Yalin S, Bagis S, Polat G, Dogruer N, Cenk Aksit S, Hatungil R, Erdogan C. Is there a role of free oxygen radicals in primary male osteoporosis? Clin. Exp. Rheumatol. 2005; 23:689-692. [PubMed: 16173248]

18. Mangiafico RA, Malaponte G, Pennisi P, Li Volti G, Trovato G, Mangiafico M, Bevelacqua Y, Mazza F, Fiore CE. Increased formation of 8-iso-prostaglandin F(2alpha) is associated with altered bone metabolism and lower bone mass in hypercholesterolaemic subjects. J. Intern. Med. 2007; 261:587-596. [PubMed: 17547714]

19. Ostman B, Michaelsson K, Helmersson J, Byberg L, Gedeborg R, Melhus H, Basu S. Oxidative stress and bone mineral density in elderly men: antioxidant activity of a-tocopherol. Free Radic. Biol. Med. 2009; 47:668-673. [PubMed: 19500667]

20. Sanchez-Rodriguez MA, Ruiz-Ramos M, Correa-Munoz E, Mendoza-Nunez VM. Oxidative stress as a risk factor for osteoporosis in elderly Mexicans as characterized by antioxidant enzymes. BMC Musculoskeletal Disord. 2007; 8:124.

21. Hinoi E, Takarada T, Fujimori S, Wang L, Iemata M, Uno K, Yoneda Y. Nuclear factor E2 p45related factor 2 negatively regulates chondrogenesis. Bone. 2007; 40:337-344. [PubMed: 17029980]

22. Kwak MK, Wakabayashi N, Greenlaw JL, Yamamoto M, Kensler TW. Antioxidants enhance mammalian proteasome expression through the Keap1-Nrf2 signaling pathway. Mol. Cell. Biol. 2003; 23:8786-8794. [PubMed: 14612418]

23. Leung L, Kwong M, Hou S, Lee C, Chan JY. Deficiency of the Nrf1 and Nrf2 transcription factors results in early embryonic lethality and severe oxidative stress. J. Biol. Chem. 2003; 278:4802148029. [PubMed: 12968018]

24. Zhu H, Zhang L, Itoh K, Yamamoto M, Ross D, Trush MA, Zweier JL, Li Y. Nrf2 controls bone marrow stromal cell susceptibility to oxidative and electrophilic stress. Free Radic. Biol. Med. 2006; 41:132-143. [PubMed: 16781461]

25. Aoki Y, Sato H, Nishimura N, Takahashi S, Itoh K, Yamamoto M. Accelerated DNA adduct formation in the lung of the Nrf2 knockout mouse exposed to diesel exhaust. Toxicol. Appl. Pharmacol. 2001; 173:154-160. [PubMed: 11437637]

26. Chan K, Kan YW. Nrf2 is essential for protection against acute pulmonary injury in mice. Proc. Natl. Acad. Sci. USA. 1999; 96:12731-12736. [PubMed: 10535991] 
27. Enomoto A, Itoh K, Nagayoshi E, Haruta J, Kimura T, O’Connor T, Harada T, Yamamoto M. High sensitivity of Nrf2 knockout mice to acetaminophen hepatotoxicity associated with decreased expression of ARE-regulated drug metabolizing enzymes and antioxidant genes. Toxicol. Sci. 2001; 59:169-177. [PubMed: 11134556]

28. Hirayama A, Yoh K, Nagase S, Ueda A, Itoh K, Morito N, Hirayama K, Takahashi S, Yamamoto M, Koyama A. EPR imaging of reducing activity in Nrf2 transcriptional factor-deficient mice. Free Radic. Biol. Med. 2003; 34:1236-1242. [PubMed: 12726911]

29. Chan K, Han XD, Kan YW. An important function of Nrf2 in combating oxidative stress: detoxification of acetaminophen. Proc. Natl. Acad. Sci. USA. 2001; 98:4611-4616. [PubMed: 11287661]

30. Cho HY, Jedlicka AE, Reddy SP, Kensler TW, Yamamoto M, Zhang LY, Kleeberger SR. Role of NRF2 in protection against hyperoxic lung injury in mice. Am. J. Respir. Cell Mol. Biol. 2002; 26:175-182. [PubMed: 11804867]

31. Cho HY, Jedlicka AE, Reddy SP, Zhang LY, Kensler TW, Kleeberger SR. Linkage analysis of susceptibility to hyperoxia: Nrf2 is a candidate gene. Am. J. Respir. Cell Mol. Biol. 2002; 26:4251. [PubMed: 11751202]

32. Yoh K, Itoh K, Enomoto A, Hirayama A, Yamaguchi N, Kobayashi M, Morito N, Koyama A, Yamamoto M, Takahashi S. Nrf2-deficient female mice develop lupus-like autoimmune nephritis. Kidney Int. 2001; 60:1343-1353. [PubMed: 11576348]

33. Braun S, Hanselmann C, Gassmann MG, auf dem Keller U, Born-Berclaz C, Chan K, Kan YW, Werner S. Nrf2 transcription factor, a novel target of keratinocyte growth factor action which regulates gene expression and inflammation in the healing skin wound. Mol. Cell. Biol. 2002; 22:5492-5505. [PubMed: 12101242]

34. Ozgocmen S, Kaya H, Fadillioglu E, Aydogan R, Yilmaz Z. Role of antioxidant systems, lipid peroxidation, and nitric oxide in postmenopausal osteoporosis. Mol. Cell. Biochem. 2007; 295:4552. [PubMed: 16841180]

35. Lee NK, Choi YG, Baik JY, Han SY, Jeong DW, Bae YS, Kim N, Lee SY. A crucial role for reactive oxygen species in RANKL-induced osteoclast differentiation. Blood. 2005; 106:852-859. [PubMed: 15817678]

36. Travis EL, Rachakonda G, Zhou X, Korhonen K, Sekhar KR, Biswas S, Freeman ML. NRF2 deficiency reduces life span of mice administered thoracic irradiation. Free Radic. Biol. Med. 2011; 51:1175-1183. [PubMed: 21712086]

37. Siva S, Chesson B, Aarons Y, Clements N, Kron T, MacManus M, Ball D. Implementation of a lung radiosurgery program: technical considerations and quality assurance in an Australian institution. J. Med. Imaging Radiat. Oncol. 2012; 56:354-361. [PubMed: 22697336]

38. Goldwein JW. Effects of radiation therapy on skeletal growth in childhood. Clin. Orthop. Relat. Res. 1991; 262:101-107. [PubMed: 1984904]

39. Ohrnell LO, Branemark R, Nyman J, Nilsson P, Thomsen P. Effects of irradiation on the biomechanics of osseointegration: an experimental in vivo study in rats. Scand. J. Plast. Reconstr. Surg. Hand Surg. 1997; 31:281-293. [PubMed: 9444704]

40. Biswas S, Nyman JS, Alvarez J, Chakrabarti A, Ayres A, Sterling J, Edwards J, Rana T, Johnson R, Perrien DS, Lonning S, Shyr Y, Matrisian LM, Mundy GR. Anti-transforming growth factor ss antibody treatment rescues bone loss and prevents breast cancer metastasis to bone. PLoS One. 6:e27090. [PubMed: 22096521]

41. Beyer TA, Werner S. The cytoprotective Nrf2 transcription factor controls insulin receptor signaling in the regenerating liver. Cell Cycle. 2008; 7:874-878. [PubMed: 18414027]

42. Bellows CG, Heersche JN, Aubin JE. Effects of dexamethasone on expression and maintenance of cartilage in serum-containing cultures of calvaria cells. Cell Tissue Res. 1989; 256:145-151. [PubMed: 2713890]

43. Robey PG, Termine JD. Human bone cells in vitro. Calcif. Tissue Int. 1985; 37:453-460. [PubMed: 2998572]

44. Bai XC, Lu D, Liu AL, Zhang ZM, Li XM, Zou ZP, Zeng WS, Cheng BL, Luo SQ. Reactive oxygen species stimulates receptor activator of NF-kappaB ligand expression in osteoblast. J. Biol. Chem. 2005; 280:17497-17506. [PubMed: 15731115] 
45. Willey JS, Lloyd SA, Robbins ME, Bourland JD, Smith-Sielicki H, Bowman LC, Norrdin RW, Bateman TA. Early increase in osteoclast number in mice after whole-body irradiation with 2 Gy X rays. Radiat. Res. 2008; 170:388-392. [PubMed: 18763868]

46. Morse ML, Dahl RH. Cellular glutathione is a key to the oxygen effect in radiation damage. Nature. 1978; 271:660-662. [PubMed: 342974]

47. Revesz L, Bergstrand H, Modig H. Intrinsic nonprotein sulphydryl levels and cellular radiosensitivity. Nature. 1963; 198:1275-1277. [PubMed: 13981853]

48. Kensler TW, Wakabayashi N, Biswal S. Cell survival responses to environmental stresses via the Keap1-Nrf2-ARE pathway. Annu. Rev. Pharmacol. Toxicol. 2007; 47:89-116. [PubMed: 16968214]

49. McMahon M, Itoh K, Yamamoto M, Chanas SA, Henderson CJ, McLellan LI, Wolf CR, Cavin C, Hayes JD. The Cap'n'Collar basic leucine zipper transcription factor Nrf2 (NF-E2 p45-related factor 2) controls both constitutive and inducible expression of intestinal detoxification and glutathione biosynthetic enzymes. Cancer Res. 2001; 61:3299-3307. [PubMed: 11309284]

50. Alam J, Stewart D, Touchard C, Boinapally S, Choi AM, Cook JL. Nrf2, a Cap'n'Collar transcription factor, regulates induction of the heme oxygenase-1 gene. J. Biol. Chem. 1999; 274:26071-26078. [PubMed: 10473555]

51. Moinova HR, Mulcahy RT. Up-regulation of the human $\gamma$-glutamylcysteine synthetase regulatory subunit gene involves binding of Nrf-2 to an electrophile responsive element. Biochem. Biophys. Res. Commun. 1999; 261:661-668. [PubMed: 10441483]

52. Cao X, Wu X, Frassica D, Yu B, Pang L, Xian L, Wan M, Lei W, Armour M, Tryggestad E, Wong J, Wen CY, Lu WW, Frassica FJ. Irradiation induces bone injury by damaging bone marrow microenvironment for stem cells. Proc. Natl. Acad. Sci. USA. 2011; 108:1609-1614. [PubMed: 21220327]

53. Seeman E. Bone modeling and remodeling. Crit. Rev. Eukaryotic Gene Expression. 2009; 19:219233.

54. Gimble JM, Robinson CE, Wu X, Kelly KA. The function of adipocytes in the bone marrow stroma: an update. Bone. 1996; 19:421-428. [PubMed: 8922639]

55. Beresford JN, Bennett JH, Devlin C, Leboy PS, Owen ME. Evidence for an inverse relationship between the differentiation of adipocytic and osteo-genic cells in rat marrow stromal cell cultures. J. Cell Sci. 1992; 102(Pt 2):341-351. [PubMed: 1400636]

56. Chartoumpekis DV, Ziros PG, Sykiotis GP, Zaravinos A, Psyrogiannis AI, Kyriazopoulou VE, Spandidos DA, Habeos IG. Nrf2 activation diminishes during adipocyte differentiation of ST2 cells. Int. J. Mol. Med. 2011; 28:823-828. [PubMed: 21805027]

57. Lee H, Lee YJ, Choi H, Ko EH, Kim JW. Reactive oxygen species facilitate adipocyte differentiation by accelerating mitotic clonal expansion. J. Biol. Chem. 2009; 284:10601-10609. [PubMed: 19237544]

58. Hinoi E, Fujimori S, Wang L, Hojo H, Uno K, Yoneda Y. Nrf2 negatively regulates osteoblast differentiation via interfering with Runx2-dependent transcriptional activation. J. Biol. Chem. 2006; 281:18015-18024. [PubMed: 16613847]

59. Zhang J, Niu C, Ye L, Huang H, He X, Tong WG, Ross J, Haug J, Johnson T, Feng JQ, Harris S, Wiedemann LM, Mishina Y, Li L. Identification of the haematopoietic stem cell niche and control of the niche size. Nature. 2003; 425:836-841. [PubMed: 14574412]

60. Gori F, Hofbauer LC, Dunstan CR, Spelsberg TC, Khosla S, Riggs BL. The expression of osteoprotegerin and RANK ligand and the support of osteoclast formation by stromal-osteoblast lineage cells is developmentally regulated. Endocrinology. 2000; 141:4768-4776. [PubMed: 11108292]

61. Calvi LM, Adams GB, Weibrecht KW, Weber JM, Olson DP, Knight MC, Martin RP, Schipani E, Divieti P, Bringhurst FR, Milner LA, Kronenberg HM, Scadden DT. Osteoblastic cells regulate the haematopoietic stem cell niche. Nature. 2003; 425:841-846. [PubMed: 14574413]

62. Lacey DL, Timms E, Tan HL, Kelley MJ, Dunstan CR, Burgess T, Elliott R, Colombero A, Elliott G, Scully S, Hsu H, Sullivan J, Hawkins N, Davy E, Capparelli C, Eli A, Qian YX, Kaufman S, Sarosi I, Shalhoub V, Senaldi G, Guo J, Delaney J, Boyle WJ. Osteoprotegerin ligand is a cytokine 
that regulates osteoclast differentiation and activation. Cell. 1998; 93:165-176. [PubMed: 9568710]

63. Yasuda H, Shima N, Nakagawa N, Yamaguchi K, Kinosaki M, Mochizuki S, Tomoyasu A, Yano K, Goto M, Murakami A, Tsuda E, Morinaga T, Higashio K, Udagawa N, Takahashi N, Suda T. Osteoclast differentiation factor is a ligand for osteoprotegerin/osteoclastogenesis-inhibitory factor and is identical to TRANCE/RANKL. Proc. Natl. Acad. Sci. USA. 1998; 95:3597-3602. [PubMed: 9520411]

64. Simonet WS, Lacey DL, Dunstan CR, Kelley M, Chang MS, Luthy R, Nguyen HQ, Wooden S, Bennett L, Boone T, Shimamoto G, DeRose M, Elliott R, Colombero A, Tan HL, Trail G, Sullivan J, Davy E, Bucay N, Renshaw-Gegg L, Hughes TM, Hill D, Pattison W, Campbell P, Sander S, Van G, Tarpley J, Derby P, Lee R, Boyle WJ. Osteoprotegerin: a novel secreted protein involved in the regulation of bone density. Cell. 1997; 89:309-319. [PubMed: 9108485]

65. Yasuda H, Shima N, Nakagawa N, Mochizuki SI, Yano K, Fujise N, Sato Y, Goto M, Yamaguchi K, Kuriyama M, Kanno T, Murakami A, Tsuda E, Morinaga T, Higashio K. Identity of osteoclastogenesis inhibitory factor (OCIF) and osteoprotegerin (OPG): a mechanism by which OPG/OCIF inhibits osteoclastogenesis in vitro. Endocrinology. 1998; 139:1329-1337. [PubMed: 9492069]

66. Baek KH, Oh KW, Lee WY, Lee SS, Kim MK, Kwon HS, Rhee EJ, Han JH, Song KH, Cha BY, Lee KW, Kang MI. Association of oxidative stress with postmenopausal osteoporosis and the effects of hydrogen peroxide on osteoclast formation in human bone marrow cell cultures. Calcif. Tissue Int. 2010; 87:226-235. [PubMed: 20614110]

67. McDonald JT, Kim K, Norris AJ, Vlashi E, Phillips TM, Lagadec C, Della Donna L, Ratikan J, Szelag H, Hlatky L, McBride WH. Ionizing radiation activates the Nrf2 antioxidant response. Cancer Res. 2010; 70:8886-8895. [PubMed: 20940400] 

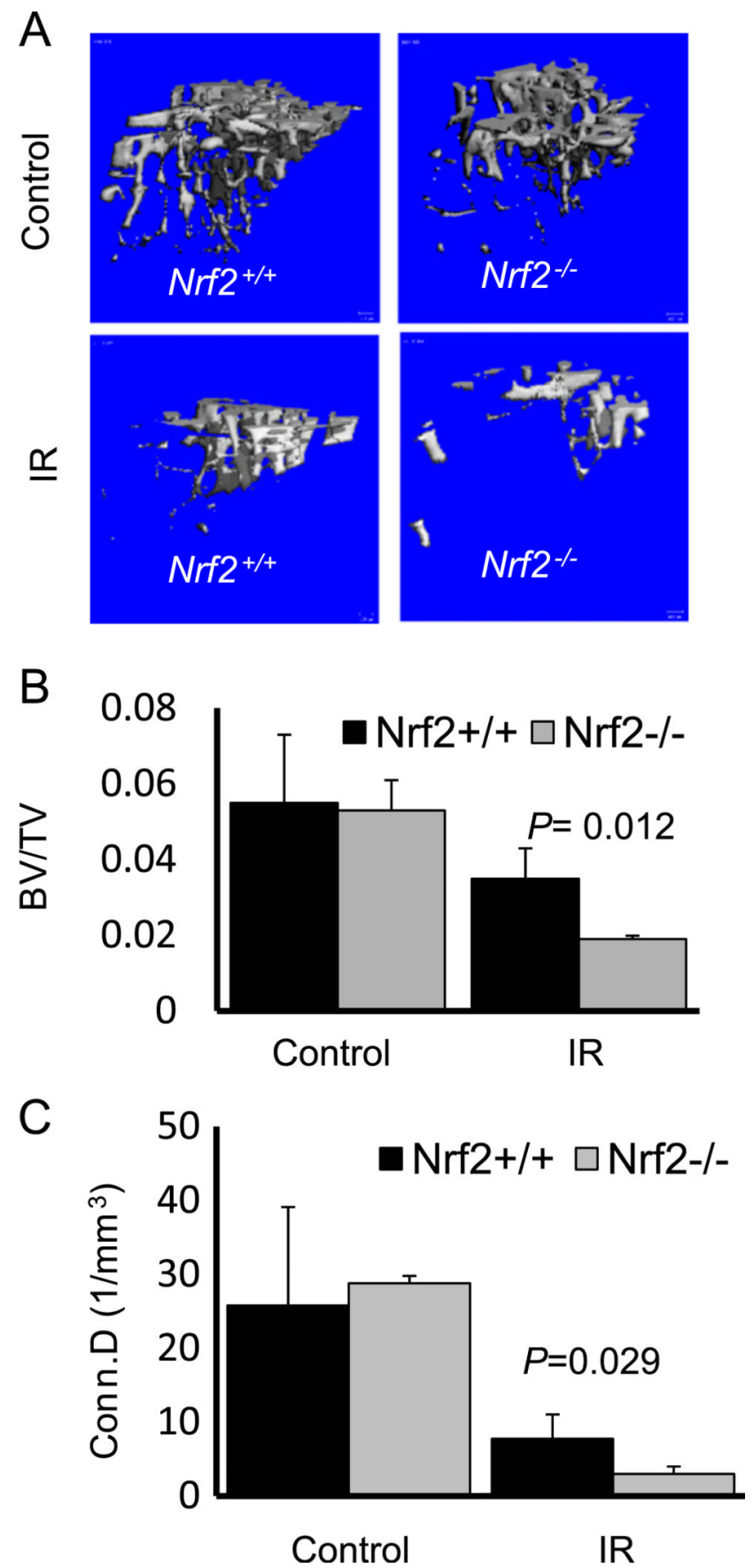

Fig. 1.

Deletion of $\mathrm{Nrf} 2$ increases IR-mediated bone loss. Three-month-old $\mathrm{Nrf} 2^{+/+}$and $\mathrm{Nrf} 2^{-/-}$ mice were irradiated in both hindlegs, bone samples were collected 1 month after radiation, and microCT analysis was performed. (A) Representative 3D reconstruction of microCT images of the tibiae from $\mathrm{Nrf}^{+/+}$and $\mathrm{Nrf} 2^{-/-}$mice, 1 month after 20 Gy hindleg irradiation. (B) Average trabecular bone volume (BV/TV) and (C) connectivity density (Conn.D) assessed from microCT analysis from the same experiment. Statistical analysis was performed using Student's $t$ test. $P<0.05$ was considered significant. At least five mice were included in each group for this experiment. 


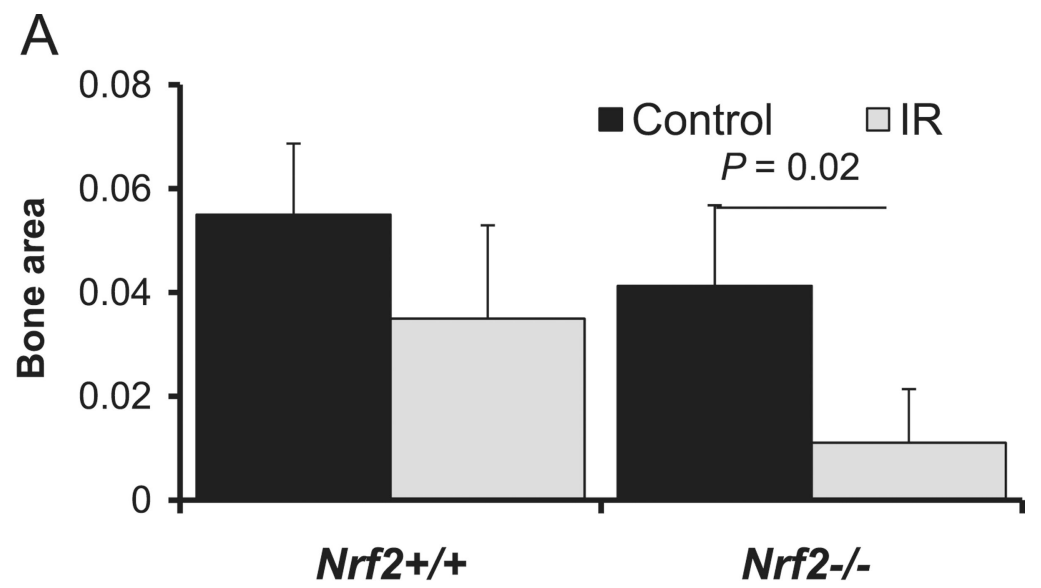

B

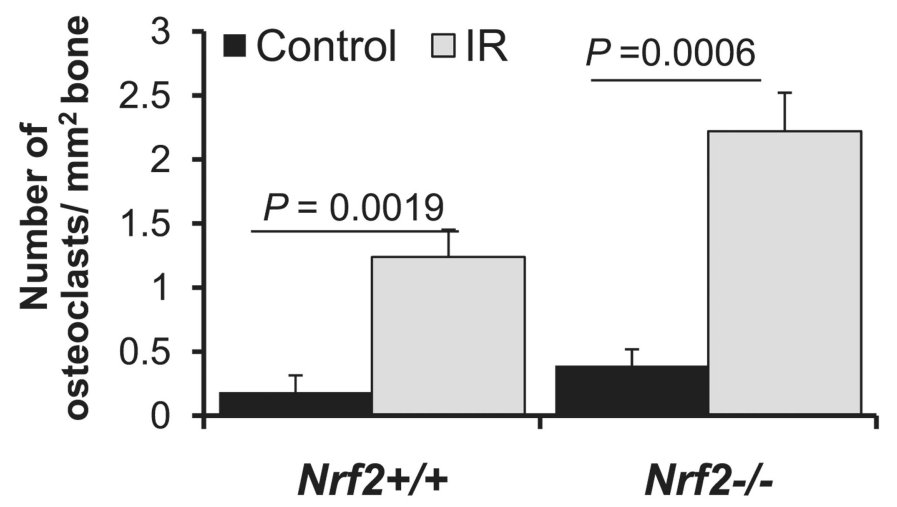

C

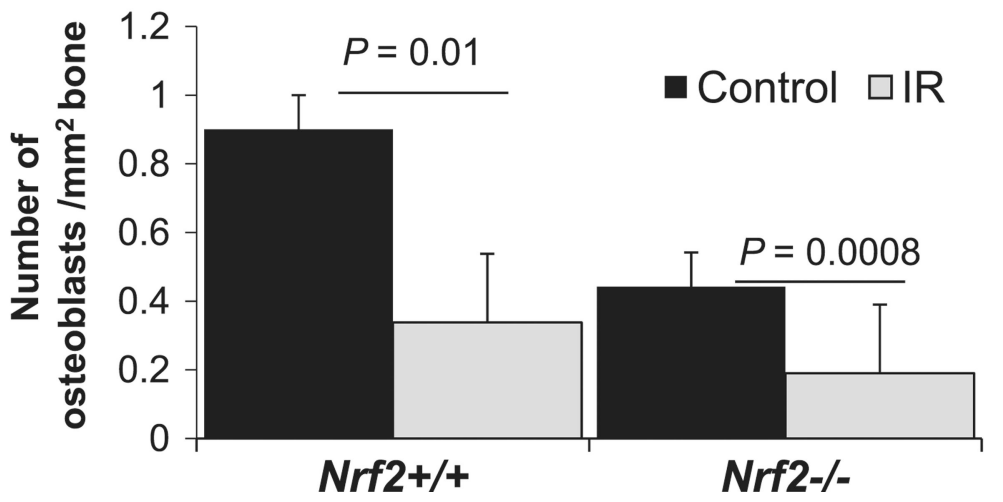

Fig. 2.

IR exposure significantly reduces bone area in the absence of $N r f 2$. Mice were irradiated (20 Gy, single-dose hindleg exposure) at 3 months of age and bone samples were collected 1 month after irradiation. Tissue samples were processed and histology was done as described under Materials and methods. (A) Average bone area before and after irradiation in $\mathrm{Nrf}^{+/+}$ and $\mathrm{Nrf}^{-/-}$mice. Numbers of (B) osteoclasts and (C) osteoblasts per square millimeter of bone in $\mathrm{Nrf2} 2^{+/+}$and $\mathrm{Nrf}^{-/-}$mice with and without irradiation. At least five mice were included in each group for this experiment. 

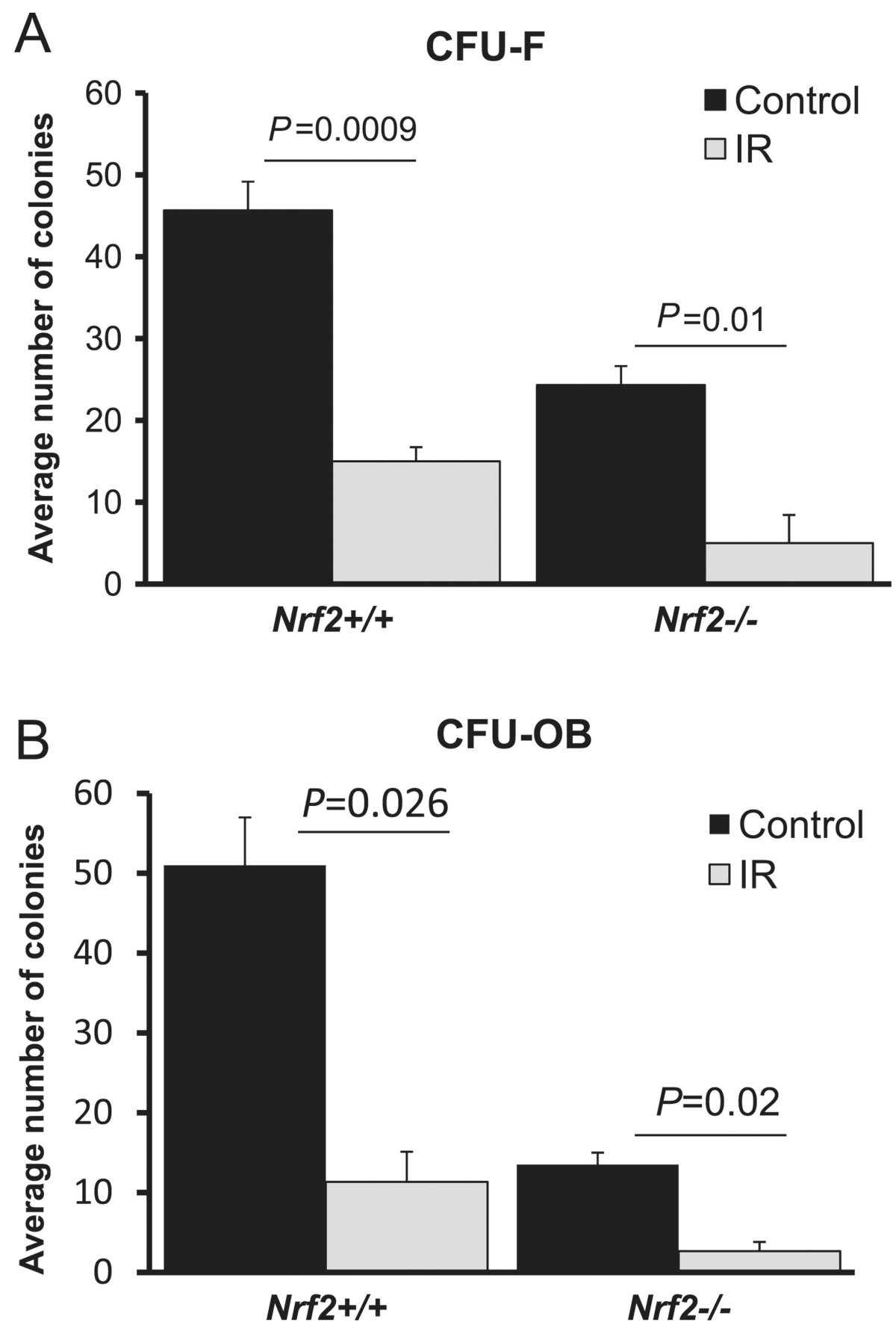

Fig. 3.

Radiation decreases survival of osteoblasts in $\mathrm{Nrf}^{+/+}$and $\mathrm{Nrf}^{-/-}$mice. Mice were irradiated in both hindlegs and bone marrow stromal cells were collected 3 days later. Control bone marrow was also collected from age- and sex-matched mice and cultured as outlined under Materials and methods. (A) Average number of fibroblast colony-forming units (CFU-F) per $1 \times 10^{6}$ bone marrow cells. (B) Average number of osteoblast colonyforming units $(\mathrm{CFU}-\mathrm{OB})$ per $2 \times 10^{6}$ bone marrow cells. 

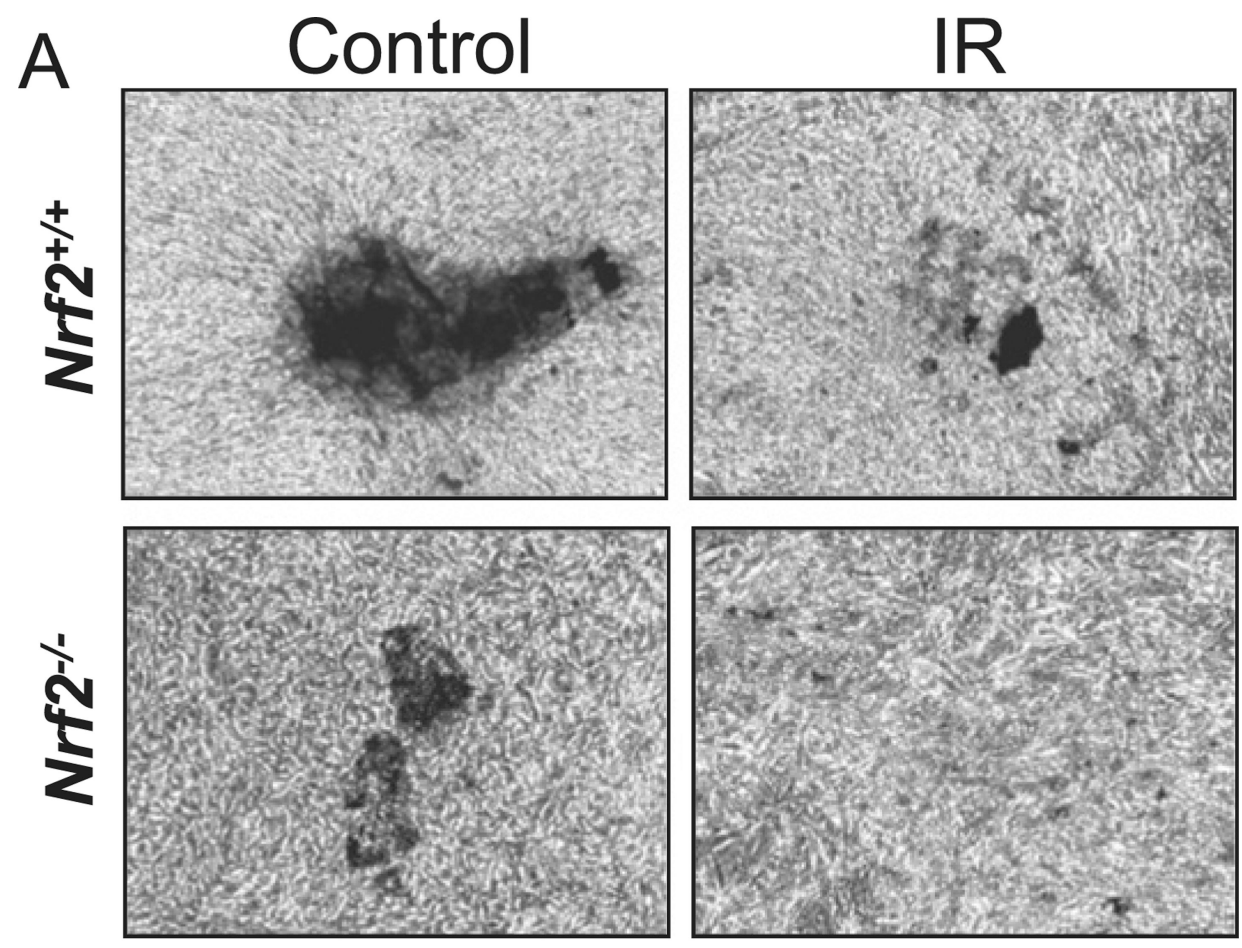

B

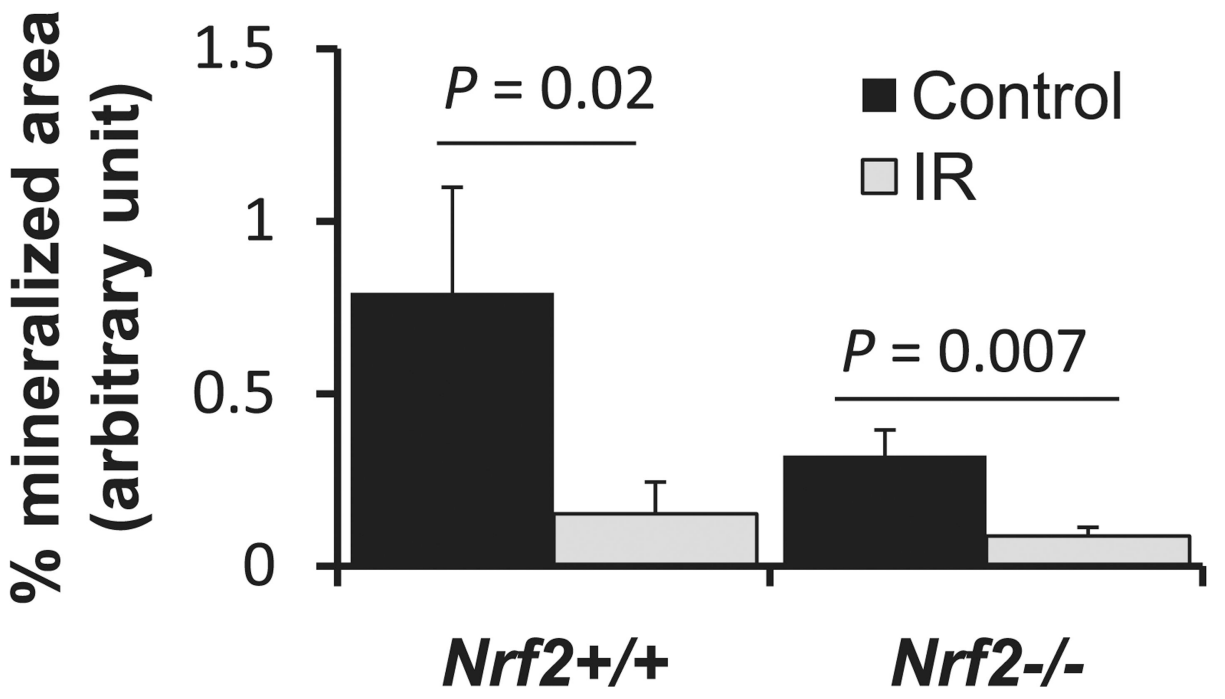

Fig. 4.

Lack of $N r f 2$ sensitizes calvarial osteoblasts toward an IR-induced decrease in osteoblast mineralization. Ex vivo osteoblast mineralization assay using calverial osteoblasts from $\mathrm{Nrf}^{2 /+}$ and $\mathrm{Nrf}^{2--}$ mice was performed. After 20Gy irradiation, osteoblasts were cultured in the presence of osteogenic medium until mineralized nodule formation was noted (approximately 14 days) as described under Materials and methods. (A) Representative images of mineralized matrix formation. (B) Quantification of mineralization images in (A). Student's $t$ test was performed to calculate $P$ values; $n=5$ for each group and the experiment was performed at least three times. 
A

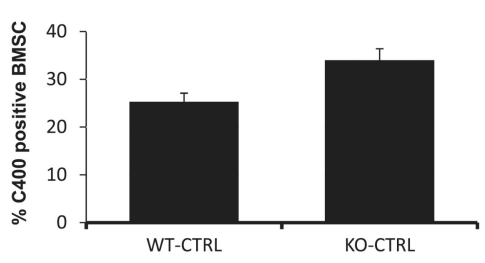

C

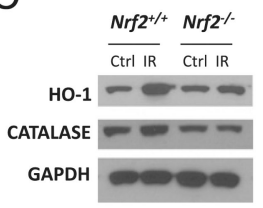

$E$
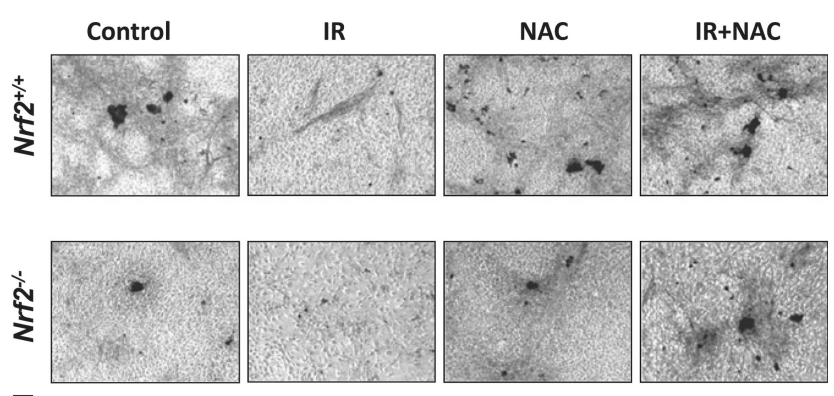

$\mathrm{F}$

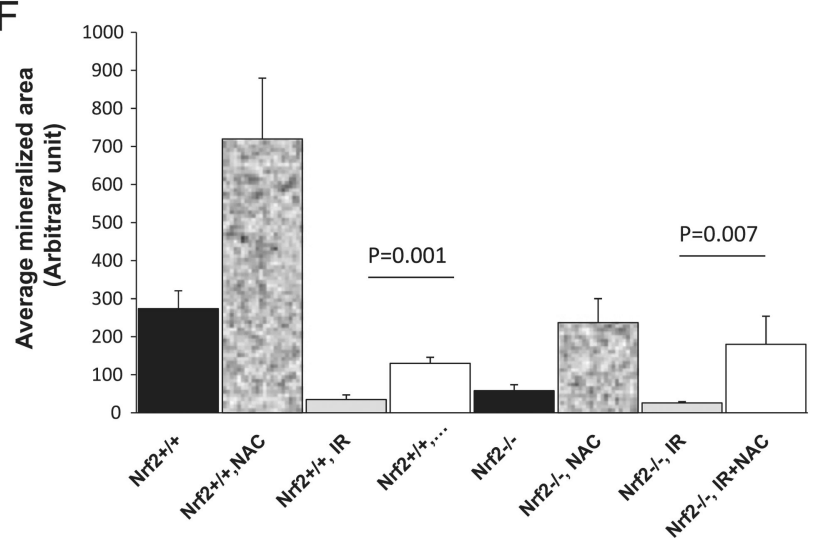

Fig. 5.

Lack of Nrf2 increases oxidative stress. (A) To assess whether lack of Nrf2 leads to increased oxidative stress, the level of reactive oxygen species was measured in bone marrow stromal cells from $\mathrm{Nrf2}^{+/+}$and $\mathrm{Nrf2}^{-/-}$mice by detecting oxidation of C400. (B) Total GSH level was measured in bone marrow stromal cells at 1 and $19 \mathrm{~h}$ postradiation time points (see Materials and Methods for details). (C) Representative immunoblot showing the expression of $\mathrm{HO} 1$ and catalase from $\mathrm{Nrf}^{+/+}$and $\mathrm{Nrf2}^{-/-}$mouse calverial osteoblasts with or without radiation exposure ( $24 \mathrm{~h}$ post-IR). Samples were collected $24 \mathrm{~h}$ after radiation exposure ex vivo. (D) Densitometric analysis of the relative expression of $\mathrm{HO} 1$ and catalase using ImageJ. (E) Calvarial osteoblasts from $\mathrm{Nrf2}^{+/+}$and $\mathrm{Nrf}^{-\mathrm{I}^{-}}$mice were exposed to 20 Gy single-dose radiation, NAC treatment, or a combination of both or were left untreated. Representative images of mineralized matrix formation under each condition are shown. (F) Quantification of VonKossa staining images from at least three different fields from two representative experiments using Metamorph software. 

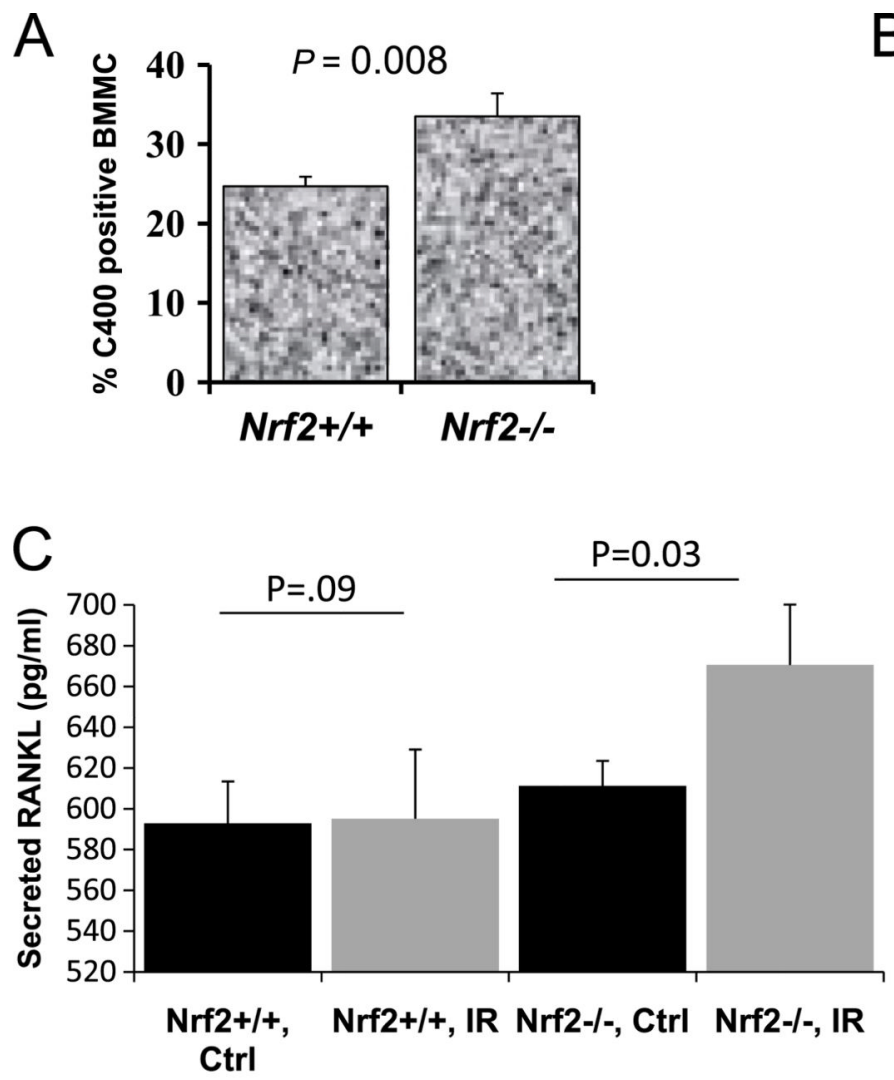

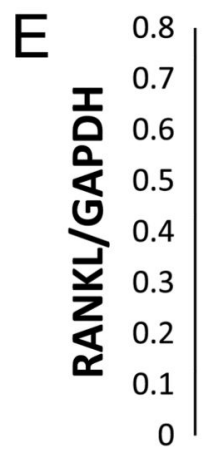
Ctrl
B
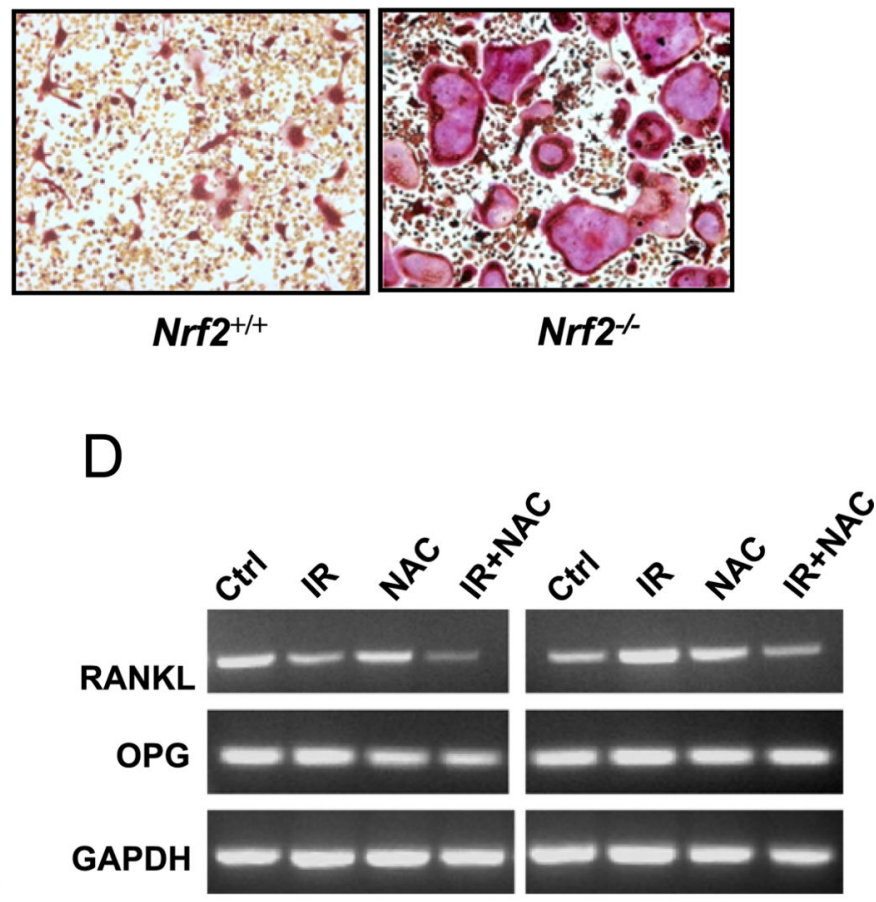

$\mathrm{Nrf2}^{+/+}$

Nrf2-- 
Quantification of RANKL expression by RT-PCR (normalized by GAPDH) using ImageJ software. 


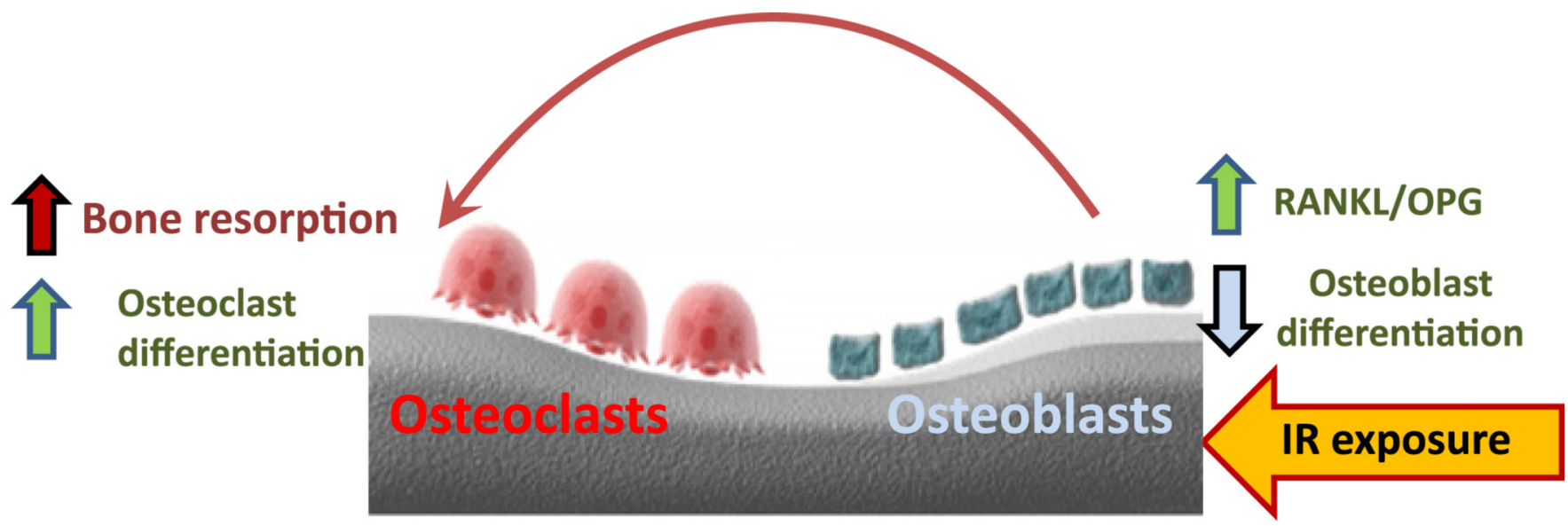

Fig. 7.

Proposed model of IR-mediated bone loss in the absence of Nrf2. Exposure to IR negatively affects osteoblast differentiation. A large pool of undifferentiated osteoblasts may increase the amount of RANKL secreted and induce osteoclastic bone resorption. In addition, increased oxidative stress in absence of Nrf2 may also contribute to the differentiation and maturation of osteoclasts. 
Table 1

Effect of radiation on the cycle of bone marrow stromal cells.

\begin{tabular}{lrccc}
\hline Bone marrow mononuclear cells & Sub-G0 & G1 & S & G2 \\
\hline$N r f 2^{+/+}$untreated & 23.3 & 70.3 & 4.5 & 1.4 \\
$N r f 2^{+/+}$IR & 37.3 & 51.1 & 4.6 & 3.7 \\
$N r f 2^{-/-}$untreated & 9.6 & 79.3 & 7.1 & 2.1 \\
$N r f 2^{-/-}$IR & 44.7 & 43.5 & 6.9 & 2.4 \\
\hline
\end{tabular}

Bone marrow cells were flushed from mouse tibiae and plated in a-MEM. After 2-3 days, attached cells were exposed to 20 Gy irradiation (IR). After $24 \mathrm{~h}$, the cells were detached and washed in PBS and cell cycle analysis was performed using propidium iodide staining by flow cytometry. A separate set of nonirradiated cells was stained and analyzed in parallel and compared with irradiated cells. 